\title{
Serum prolactin levels in differential diagnosis of pediatric epileptic and nonepileptic (pseudo-SEIZURES) seizures
}

\author{
Hatice Bülbül Çitilcioğlu', Selçuk Matyar², Okan Akgül' ${ }^{1}$ İbrahim Hakan Bucak², Mehmet Turgut ${ }^{3}$
}

The aim was to determine diagnostic value of serum prolactin levels in the differential diagnosis of epileptic and nonepileptic seizures in children. The study included 100 patients aged one month to 18 years, admitted to the hospital for seizure complaints. All patients underwent electroencephalography in the postictal period and their serum prolactin levels were measured at $10 \mathrm{~min}$ and $60 \mathrm{~min}$ of the postictal period. The mean 10-min serum prolactin level was $37.1 \pm 20.09 \mathrm{ng} / \mathrm{mL}$ and $16 \pm 14.59 \mathrm{ng} / \mathrm{mL}(p<0.01)$ in patients with epileptic and nonepileptic seizures, respectively. After grouping of patients with nonepileptic seizures, the mean 10-min serum prolactin level in patients with epileptic seizures and those with syncope was $37.1 \pm 20.09 \mathrm{ng} / \mathrm{mL}$ and $30.52 \pm 19.21 \mathrm{ng} / \mathrm{mL}(p>0.05)$, respectively. The mean 10-min prolactin level in patients with epileptic seizures and those with non-syncope epileptic seizures (night terror, conversion and breath holding spells) was $37.1 \pm 20.09 \mathrm{ng} / \mathrm{mL}$ and $10.9 \pm 5.95 \mathrm{ng} / \mathrm{mL}(p<0.01)$, respectively. In conclusion, serum prolactin level in the postictal period is an important marker in the differential diagnosis of epileptic and nonepileptic seizures. There was no significant difference between serum prolactin levels in the differential diagnosis of epileptic seizures and syncope, but it had an important role in differentiating nonepileptic cases such as breath holding spells, night terror and hysterical conversions from epileptic seizures and syncope.

Keywords: prolactin; epilepsy; epilepsy, post-traumatic; syncope

\section{INTRODUCTION}

Epileptic seizure (ES) is a clinical condition made up of temporary symptoms and/or findings due to abnormally excessive and synchronized neuronal discharges in the brain (1). Epilepsy is a tendency of the brain to form epileptic seizures plus at least one epileptic seizure (2). Clinical and electrographic classifications of epileptic seizures were issued by the International League against Epilepsy (ILAE) in 1981 and are still widely accepted throughout the world (3). We may encounter epilepsy in many clinical forms. The clinical properties, etiology, severity and prognosis of epilepsy with concomitant neurological findings are highly variable. For this reason, the differential diagnosis of epilepsy and nonepileptic seizures (NES) may be difficult (4). The authors report that $20 \%-25 \%$ of patients who are referred to epilepsy clinic do not really have epilepsy (5). Similarly, 10\%-15\% of children diagnosed with treatment-resistant epilepsy actually have nonepileptic attacks (6). The most common misdiagnoses include syncope (44\%), psychiatric disorders (20\%), breath holding spells (11\%), migraine and night terror (12\%), and other rare reasons (11\%) (5).

Prolactin (PRL) is a polypeptide hormone secreted from the lactotrope cells of the anterior hypophysis and its secretion affects sleep, stress, surgical interventions and antiepileptic

'Department of Pediatrics, Adana Numune Education and Research Hospital, Adana

${ }^{2}$ Department of Biochemistry, Adana Numune Education and Research Hospital, Adana

${ }^{3}$ Department of Pediatrics, Adıyaman University School of Medicine, Adıyaman, Turkey

This study was carried out at Adana Numune Education and Research Hospital, Adana, Turkey.

\section{Correspondence to:}

Assist. Prof. İbrahim Hakan Bucak, MD; Adiyaman University School of Medicine; Department of Pediatrics, Atatürk St:; 02200 Adiyaman, Turkey; e-mail: ihbucak@hotmail.com

Primljeno/Received: 11. 8. 2015., Prihvaćeno/Accepted: 12. 10. 2015. 
medication $(7,8)$. The increase in PRL levels following an ES has been known for approximately 40 years (9). It has also been proven that the type, localization and duration of the seizure affect PRL secretion (10). Video-electroencephalography (video-EEG) is definitely the gold standard in the differential diagnosis of ES and NES. However, it is not applicable in emergency services. Although there are many studies evaluating PRL levels in the postictal period for the differential diagnosis of ES and NES, the studies done on children are limited.

In our study, it was aimed to measure serum PRL levels at 10 and 60 min for the differential diagnosis of ES and NES in children aged one month to 18 years.

\section{PATIENTS AND METHODS}

The study was carried out at the Adana Numune Education and Research Hospital, Adana, Turkey (ethical approval no. 31032010/17). The study included 131 children aged one month to 18 years, referred to our Pediatrics and Emergency Policlinics, Adana Numune Research and Training Hospital, for seizure complaints. An informed consent was obtained from parents/guardians of all study participants. As the study was planned as a prospective one, 31 cases with liver and/or kidney dysfunction, electrolyte imbalance, findings of intracranial infection, or a history of medication use other than antiepileptic medications were excluded.

The cases were divided into patient and control groups. Patient group included 50 patients (32 female and 18 male) admitted to our pediatrics and/or emergency units within 10 minutes of seizure complaint and thought to have sustained ES after detailed history and physical examination (group 1). Another 50 patients (29 female and 21 male) admitted to our pediatrics and/or emergency units within 10 minutes of seizure complaint and thought to have had NES after detailed history and physical examination were included in control group (group 2). Sleep EEG was performed in patients of both groups only once in the postictal period, approximately ten days after admission to the hospital.

Venous blood was drawn in all patients at postictal $10 \mathrm{~min}$ and 60 min using 5-mL vacuumed tubes without anticoagulants. The samples were kept at room temperature for coagulation and centrifuged for $10 \mathrm{~min}$ at $3000 \mathrm{G}$. Sample PRL levels were measured on an ADVIA Centaur XP (Siemens Healthcare Diagnostics Inc., Tarrytown, USA), a fully automated immunoautoanalyzer with original Siemens kits using the chemiluminometric method. The reference range of serum PRL was 2.1-17.7 ng/mL (11).

\section{Statistical analysis}

Statistical data analysis was done by use of the SPSS 15.00 package program. Mann Whitney $U$ test, used on compari- son of two groups that did not show normal distribution and Kruskal Wallis test was used on general comparison among more than two groups. Dual Mann Whitney $U$ test was used for significant findings obtained on comparison of more than two groups, while Bonferroni-adjusted Mann Whitney $U$ test was used on comparison of subgroups. Spearman rank correlation analysis was used to analyze correlation between quantitative measurements. The level of significance was set at $p=0.05$ in all tests.

\section{RESULTS}

The mean age of 50 patients in group 1 (epileptic seizure group, patient group) was 5.8 \pm 5.3 years; there were 32 (64\%) female and 18 (36\%) male patients. The mean age of 50 patients in group 2 (nonepileptic seizure group, control group) was $11 \pm 5.8$ years; there were 29 (58\%) female and 21 (42\%) male patients. The mean age was significantly lower in the epileptic seizure group $(p<0.001)$. There was no statistically significant between-group difference according to gender ( $\mathrm{p}>0.05)$.

Twenty-three group 1 patients had been previously diagnosed with epilepsy and 21 of them had been using antiepileptic medications. The remaining 27 patients were newly diagnosed. When the groups were compared according to the duration of seizures, no significant difference was found between the groups ( $p>0.05$ ). The interictal EEGs of 38 patients were interpreted as pathological. EEGs were normal in all group 2 patients. In group 2, 15 (30\%) patients were diagnosed with syncope, 20 (40\%) with conversion, ten (20\%) with breath holding spells, and five (10\%) with night terrors. Demographic and clinical characteristics of study patients are shown in Table 1.

When serum PRL levels were evaluated according to the postictal drawing time, the 10-min serum PRL levels were found to be statistically significantly higher in group 1 as compared with group $2(p<0.001)$, but there was no statistically significant between-group difference in serum PRL levels at 60 min ( $p>0.05$ ). The 10-min and 60-min serum PRL levels are shown in Table 2.

\section{DISCUSSION}

Convulsions account for $1 \%-2 \%$ of admissions to emergency department (12). Video-EEG is the gold standard for differential diagnosis of epilepsy in clinical setting; however, it is expensive and usually not available (13). There is a known need of a parameter that can be used routinely to differentiate ES and NES. It has been reported that serum PRL levels, significantly increasing after ES and not significantly changing after NES except for syncope, could be used as an important 
TABLE 1. Demographic and clinical characteristics of study patients

\begin{tabular}{|c|c|c|c|c|}
\hline \multirow{2}{*}{\multicolumn{2}{|c|}{ Age (yrs) }} & Group 1 & Group 2 & $\mathrm{P}(<0.05)$ \\
\hline & & $5.83 \pm 5.29-4.37(0.17-17)^{*}$ & $11 \pm 5.75-14,085(1-17.5)^{*}$ & $<0.001$ \\
\hline \multirow[t]{2}{*}{ Gender n (\%) } & Female & $32(64)$ & $29(58)$ & $>0.05$ \\
\hline & Male & $18(36)$ & $21(42)$ & $>0.05$ \\
\hline \multicolumn{2}{|c|}{ Epileptic Seizures n (\%) } & $50(100)$ & - & $\mathrm{NE}$ \\
\hline \multicolumn{2}{|l|}{ Generalised seizures } & $43(86)$ & - & NE \\
\hline \multicolumn{2}{|l|}{ Status epilepticus } & $7(14)$ & - & $N E$ \\
\hline \multicolumn{2}{|c|}{ Non-Epileptic Seizures n (\%) } & - & $50(100)$ & NE \\
\hline \multicolumn{2}{|l|}{ Syncope } & - & $15(30)$ & $N E$ \\
\hline \multicolumn{2}{|l|}{ Conversion } & - & $20(40)$ & $\mathrm{NE}$ \\
\hline \multicolumn{2}{|l|}{ Breath holding spells } & - & $10(20)$ & NE \\
\hline \multicolumn{2}{|l|}{ Night terror } & - & $5(10)$ & NE \\
\hline \multicolumn{2}{|c|}{ Duration of seizure (min) } & $8.12 \pm 11.28,3.50(1-60)^{*}$ & $7.0 \pm 9.9,3.0(1-60)^{*}$ & $>0.05$ \\
\hline \multirow[t]{2}{*}{ EEG Findings $n(\%)$} & Abnormal & $38(76)$ & 0 & $N E$ \\
\hline & Normal & $12(24)$ & $50(100)$ & $<0.001$ \\
\hline
\end{tabular}

TABLE 2. Comparison of serum prolactin levels between the groups according to blood sampling timing

\begin{tabular}{|c|c|c|c|c|}
\hline & \multicolumn{4}{|c|}{$\begin{array}{l}\text { Prolactin (ng/ml) } \\
\text { Mean } \pm \text { standard deviation, median (min.-max.) }\end{array}$} \\
\hline & 10. minute & $\mathrm{p}$ & 60. minute & $\mathrm{P}$ \\
\hline Group 1 & $37.1 \pm 20.09,30(12-96)$ & \multirow{2}{*}{$<0.001$} & $12.66 \pm 7.01,11.8(1.9-7.7)$ & \multirow{2}{*}{$>0.05$} \\
\hline Group 2 & $16 \pm 14.59,13.35(1.7-88)$ & & $9.12 \pm 4.28,10.0(2.1-15)$ & \\
\hline Group 1 & $37.1 \pm 20.09,30(12-96)$ & \multirow{2}{*}{$>0.05$} & $12.66 \pm 7.01,11.8(1.9-7.7)$ & \multirow{2}{*}{$>0.05$} \\
\hline Group 2 (Syncope) & $30.52 \pm 19.21,25.3(19.6-88)$ & & $11.9 \pm 2.29,11.5(9.6-15)$ & \\
\hline Group 1 & $37.1 \pm 20.09,30(12-96)$ & \multirow[b]{2}{*}{$<0.001$} & $12.66 \pm 7.01,11.8(1.9-27.7)$ & \multirow[b]{2}{*}{$>0.05$} \\
\hline $\begin{array}{l}\text { Group } 2 \text { Conversion Breath Holding } \\
\text { Spell Night Terror }\end{array}$ & $10.9 \pm 5.95,8.5(1.7-29)$ & & $7.72 \pm 4.45,9.6(2.1-14)$ & \\
\hline
\end{tabular}

marker on differential diagnosis (13). The hypothesis of increased PRL secretion during the ictal period is being defended. In 1978, Trimble et al. were the first to report in the literature that PRL levels were significantly higher in patients with ES as compared with patients that had NES (9).

The studies of ES and NES in children and adolescents are highly limited. In our study, we found a statistically significant age difference between the ES and NES groups. We believe that the age increase in the NES group may be due to conversions. The American Academy of Neurology suggests evaluation of PRL levels in adults and older children to differentiate generalized tonic-clonic seizures or complex partial seizures from psychogenic NES at 10-20 min following the attack and interpreting the results in favor of generalized tonic-clonic or partial seizures in case of increased results (14). Yerby et al. (13) report that the postictal serum PRL levels used for differential diagnosis of ES and NES are not increased in nonepileptic cases in contrast to epileptic cases, and Luef (15) reports that the 15-20 min serum PRL increase may be helpful in differentiating between psycho- genic and complex partial and generalized tonic-clonic seizures but may not be of help in differentiating between epileptic seizure and syncope.

The results obtained in our study showed that serum PRL levels increased significantly in epilepsies. Considering the difference and time difference between the groups, it was found that the 10-min serum PRL levels were higher in the epileptic group as compared with the nonepileptic group $(p<0.001)$, but there was no significant difference in the 60min serum PRL levels between the epileptic and nonepileptic groups ( $p>0.05$ ). Considering difference within the groups according to timing, the 10-min serum PRL levels were higher than the 60-min serum PRL levels; the difference was statistically significant $(p<0.001)$. When syncope was compared between the nonepileptic group and other nonepileptic conditions (conversion, breath holding spell, night terror), it was found that the 10-min serum PRL levels were higher in syncope cases $(p<0.01)$.

These results showed that serum PRL levels did not help differentiate cases of syncope and epilepsies; however, simple 
laboratory tests can differentiate syncope from other nonepileptic cases (conversion, breath holding spell, night terror). These results are consistent with those described in the literature. Again consistent with other studies, our results showed that serum PRL levels did not help differentiate epilepsies and syncopes. In these studies, Oribe et al. (16) showed that serum PRL levels were as high as those seen in epilepsies in 21 patients in whom they induced syncopes with tilt test. Leuf (15) showed that PRL was not helpful in differentiation of epileptic seizure and syncope; and finally Chen et al. (14) showed that serum PRL levels were not helpful in differentiating epileptic seizure and syncope. Based on the data recorded in our study, we determined that the time of measurement was the only factor affecting PRL lev$\mathrm{el}$, and not any other factor (gender, EEG pathology, antiepileptic drug use, duration of seizures, etc.). Therefore, we believe that blood sample should be obtained from patients who are admitted to emergency policlinics with seizures (epileptic or nonepileptic) in the postictal period as soon as possible in order to evaluate PRL levels. Although we did not use PRL levels simultaneously with video-EEGs, we believe that PRL measurement is just as or even more important than video-EEGs in differentiation of ES from NES thanks to its accessibility where a laboratory is available. A limitation of this study was the fact that complex partial seizures were not taken as a separate group.

To conclude, serum PRL levels were found to be higher in the epileptic group and in syncope, which is a nonepileptic case, which is consistent with literature reports. We suggest that PRL levels be used to differentiate ES and NES in young children. We also determined that blood samples to be used for differential diagnosis should be obtained as soon as possible due to the fact that PRL reaches its peak at 10 min and regresses back to its baseline between 60 and 90 min. Extensive series of studies should be done to research the marker properties of serum PRL levels for the differential diagnosis of ES and NES in pediatric patients; timing of serum PRL measurement should be standardized; and simultaneous evaluation of serum PRL levels with video-EEGs will contribute to research in the field.

\section{NOVČANA POTPORA/FUNDING \\ Nema/None}

\section{ETIČKO ODOBRENJE/ETHICAL APPROVAL}

Nije potrebno/None

\section{SUKOB INTERESA/CONFLICT OF INTEREST}

Autori su popunili the Unified Competing Interest form na www.icmje.org/ coi_disclosure.pdf(dostupno na zahtjev) obrazac i izjavljuju: nemaju potporu niti jedne organizacije za objavljeni rad; nemaju financijsku potporu niti jedne organizacije koja bi mogla imati interes za objavu ovog rada u posljednje 3 godine; nemaju drugih veza ili aktivnosti koje bi mogle utjecati na objavljeni rad./All authors have completed the Unified Competing Interest form at www.icmje.org/coi_disclosure.pdf (available on request from the corresponding author) and declare: no support from any organization for the submitted work; no financial relationships with any organizations that might have an interest in the submitted work in the previous 3 years; no other relationships or activities that could appear to have influenced the submitted work.

\section{REFERENCES}

1. Fisher RS, Van Emde Boas W, Blume W, et al. Epileptic seizures and epilepsy: definitions proposed by the International League Against Epilepsy (ILAE) and the International Bureau for Epilepsy (IBE). Epilepsia. 2005;46(4):470-2. doi: 10.1111/j.0013-9580.2005.66104.x

2. Altunbaşak Ş. Epilepside Tanı. In: Hasanoğlu E, Düşünsel R, Bideci A, eds. Temel Pediatri. 1 ${ }^{\text {st }}$ edn. Ankara, Güneş Tıp Kitabevi; 2010:1254-56.

3. Serdaroğlu A. Epileptik Nöbet ve Sendromların Sınıflandırılması. In Hasanoğlu E, Düşünsel R, Bideci Bideci A, eds. Temel Pediatri. $1^{\text {st }}$ edn. Ankara, Güneş Tıp Kitabevi; 2010:1246-48.

4. Başoğlu M. Epilepsiler. $1^{\text {st }}$ edn. İzmir, Akal ofset; 2001.

5. Jeavons PM. Non epileptic attacks in childhood. In: Rose CF, ed. Research progress in epilepsy. London: $1^{\text {st }}$ edn. London Pitman; 1983:224-30.

6. Metrick ME, Ritter FS, Gates JR, et al. Nonepileptic events in chilhood. Epilepsia. 1991;32:322-8.

7. Sassin J, Frantz A, Weitzman E, Kapen S. Human prolactin: 24 hour pattern with increased release during sleep. Science. 1972;177:1205-07.

8. Culebras A, Miller M, Bertram L, Koch J. Differential response of growth hormone, cortisol and prolactin to seizures ang to stres. Epilepsia. 1987;28:564-70.

9. Trimble M. Serum prolactin in epilepsy and histeria. Br Med J. 1978;2:1628.

10. Malkowicz DE, Legido A, Jackel RA, et al. Prolactin secretion following repetitive seizures. Neurology. 1995;45:448-52. doi.org/10.1212/WNL.45.3.448

11. Ashby CD. Prolactin. In: Kaplan LA, Pesce AJ, ed. Methods in clinical chemistry. St. Louis, Mosby: 1987:258.

12. Adams SM, Knowles PD. Evaluation of a First Seizure. Am Fam Physician. 2007;75:1342-47.

13. Yerby MS, Van Belle G, Friel PN, et al. Serum prolactin in the diagnosis of epilepsy: sensitivity, spesifity and predictive valu. Neurology. 1987;37:1224-26. doi.org/10.1212/WNL.37.7.1224

14. Chen D, So YT, Fisher RS. Use of serum prolactin in diagnosing epileptic seizures: report of the Therapeutics and Technology Assessment Subcommittee of the American Academy of Neurology. Neurology. 2005;65:668-75. doi.org/10.1212/01.wnl.0000178391.96957.d0

15. Luef G. Hormonal alterations following seizures. Epilepsy\&Behavior. 2010;19:131-3. doi.org/10.1016/j.yebeh.2010.06.026

16. Oribe $E$, Amini $R$, Nissenbaum $E$, et al. Serum prolactin concentrations are elevated after syncope. Neurology. 1996;47:60-2. dx.doi.org/10.1212/WNL.47.1.60 


\title{
Serumske razine prolaktina u diferencijalnoj dijagnostici pedijatrijskih epileptičnih i neepileptičnih (pseudo-)napadaja
}

\author{
H. B. Çitilcioğlu, S. Matyar, O. Akgül, İ. H. Bucak, M. Turgut
}

Cilj ovoga ispitivanja bio je utvrditi dijagnostičku vrijednost serumskih razina prolaktina u diferencijalnoj dijagnostici epileptičnih i neepileptičnih napadaja u djece. U ispitivanje je bilo uključeno 100 djece u dobi od jednog mjeseca do 18 godina, primljenih u bolnicu zbog konvulzija. U svih bolesnika učinjena je elektroencefalografija u postiktalnom razdoblju, dok su njihove serumske razine prolaktina mjerene u 10. i 60. minuti postiktalnog razdoblja. Srednja 10-minutna razina prolaktina u serumu bila je 37,1 20,09

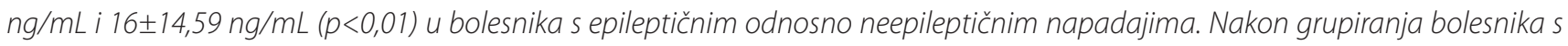
neepileptičnim napadajima 10-minutna srednja serumska razina prolaktina u bolesnika s epileptičnim napadajima i onih sa sinkopom bila je 37,1 $\pm 20,09 \mathrm{ng} / \mathrm{mL}$ odnosno 30,52 $\pm 19,21 \mathrm{ng} / \mathrm{mL}$ ( $p>0,05$ ). U bolesnika s epileptičnim napadajima i onih s ne-sinkopnim epileptičnim napadajima (noćne more, konverzija i epizode zadržavanja daha) srednja 10-minutna razina prolaktina bila je $37,1 \pm 20,09 \mathrm{ng} / \mathrm{mL}$ odnosno 10,9 $\pm 5,95 \mathrm{ng} / \mathrm{mL}$ ( $p<0,01$ ). Zaključuje se kako je serumska razina prolaktina u postiktalnom razdoblju važan biljeg u diferencijalnoj dijagnostici epileptičnih i neepileptičnih napadaja. Nije bilo značajne razlike među serumskim razinama prolaktina u diferencijalnoj dijagnostici epileptičnih napadaja i sinkope, ali je ta razina imala važnu ulogu u razlikovanju neepileptičnih slučajeva kao što su epizode zadržavanja da ha, noćne more i histerične konverzije od epileptičnih napadaja i sinkope.

Ključne riječi: prolaktin; epilepsija; epilepsija, post-traumatska; sinkopa 